\title{
Personalized medicine in lung adenocarcinoma: no longer a hope or a passing fashion, but a new reality
}

\author{
Jean-François Morère
}

Received: 4 November 2010 / Accepted: 8 November 2010/Published online: 1 December 2010

(C) Springer-Verlag 2010

In past decades, lung adenocarcinoma has simply been treated like every other non-small cell lung cancer (NSCLC). More recently, a new concept has emerged for the treatment of this kind of NSCLC: histo-guidance. A study by Scagliotti et al. [1] demonstrated different results of a new cisplatin-based chemotherapy - cisplatin-pemetrexed - depending on histology, and therapeutic strategy has since been considered distinct in adenocarcinoma and squamous-cell carcinoma. Even more recently, tyrosine-kinase inhibitors (TKI) favorably challenged the efficacy of chemotherapy in patients with mutated epithelial growth factor receptors (EGFR) [24]. These studies provide a proof of concept of personalized medicine in lung adenocarcinoma. The era when a simple pathologic examination was sufficient to decide on an accurate medical treatment is coming to an end, as we see in breast carcinoma. Today, we must consider lung adenocarcinoma not as a whole, but as a group of distinct diseases that should be treated on the basis of their different molecular profiles.

The first step is Kras testing. Kras is mutated in 25\% of patients [5]. These patients are unresponsive to anti-EGFR TKIs; one might consider anti-MEK or anti-c-met drugs for them. The next step could be looking for an EGFR mutation in the adenocarcinoma. For these patients, the key question is no longer whether to give them TKIs or chemotherapy in the first line, but rather how to improve results by overcoming the initial or acquired resistance to these drugs.

In this issue of Targeted Oncology, you will find a new lead in the review by JF Spicer and SM Rudman on BIBW

\section{J.-F. Morère $(\square)$}

Service Oncologie Médicale, Université Paris XIII,

125, Route de Stalingrad,

Bobigny, Cedex 93009, France

e-mail: jean-francois.morere@avc.ap-hop-paris.fr
2992 [6]. This new pan-erb TKI could also block c-met, which appears to be one of the main mechanisms of resistance.

In EGFR wild-type patients, we have to look for the presence of an ALK fusion protein, since ALK fusion protein and EGFR mutations are exclusive. The use of crizotinib [7] should be considered in this setting. For ALK-negative patients, Her2 and Braf could be tested, and specific drugs developed in this indication.

As we can see in this decision-making process, there are targeted answers at each step. Today, two out of ten Caucasian patients have already received targeted therapy as standard treatment with long-lasting results. New techniques such as beaming [8], SEQUENOM [9], and cmet immunochemistry [10] are already under exploration and, in the very near future, will provide comprehensive biological profiling, making it possible to provide truly targeted treatment for the vast majority of patients.

As we can see, personalized medicine is no longer a hope or a passing fashion, but a new reality.

\section{References}

1. Scagliotti GV, Parikh P, Van Pawel J et al (2008) Phase III study comparing cisplatin plus gemcitabine with cisplatin plus pemetrexed in chemotherapy-naive patients with advanced-stage non small-cell lung cancer. J Clin Oncol 26:3543-3551

2. Mok TS, Wu YL, Kim SW et al (2009) Gefitinib or carboplatinpaclitaxel in pulmonary adenocarcinoma. N Engl J Med 361 (10):947-957

3. Maemondo M, Inoue A, Kobayashi K et al (2010) Gefitinib or chemotherapy for non-small-cell lung cancer with mutated EGFR. N Engl J Med 362(25):2380-2388

4. Zhou, et al. (2010) Efficacy results from randomized phase III optimal study comparing first-line erlotinib versus carboplatin 
plus gemcitabine in Chinese non-small-cell lung cancer patients with EGFR activating mutations. 35th European Society of Medical Oncology (ESMO) Congress, October 2010, abstract LBA13

5. Ding L, Getz G, Wheeler DA et al (2008) Somatic mutations affect key pathways in lung adenocarcinoma. Nature 455:1069-1075

6. Spicer JF, Rudman SM (2010) EGFR inhibitors in non-small cell lung cancer (NSCLC): the emerging role of the dual irreversible EGFR/HER2 inhibitor BIBW 2992. Target Oncol. doi:10.1007/ s11523-010-0140-y

7. Bang Y, Kwak EL, Shaw AT, Camidge DR, Iafrate AJ, Maki RG, Solomon BJ, Ou SI, Salgia R, Clark JW (2010) Clinical activity of the oral ALK inhibitor PF-02341066 in ALK-positive patients with non-small cell lung cancer (NSCLC). J Clin Oncol 28:18s (suppl; abstr 3)
8. Beadling C, Heinrich MC, Schuff K, Druker BJ, Corless CL (2010) Mass spectroscopy-based cancer genotyping of 800 patients enrolled in a personalized cancer medicine registry. J Clin Oncol 28:15s (suppl; abstr 10503)

9. Angenendt P, David K, Juhl H, Diehl F (2010) Detection of phosphoinositide-3-kinase, catalytic, and alpha polypeptide (PIK3CA) mutations in matched tissue and plasma samples from patients with metastatic breast cancer. J Clin Oncol 28:15s (suppl; abstr 10502)

10. Schiller JH, Akerley WL, Brugger W et al (2010) Results from ARQ 197-209: a global randomized placebo-controlled phase II clinical trial of erlotinib plus ARQ 197 versus erlotinib plus placebo in previously treated EGFR inhibitor-naive patients with locally advanced or metastatic non-small cell lung cancer (NSCLC). J Clin Oncol 2010:28 (suppl., abstr LBA7502) 